ISSN: 2224-0616

Int. J . Agril. Res. Innov. \& Tech. 5(2): 16-20, December, 2015 Available online at http://www.ijarit.webs.com

\title{
QUALITY PERCEPTION OF ORGANICALLY GROWN TOMATOES (Lycopersicon esculentum Mill.) IN VIENNA, AUSTRIA
}

\author{
P.K. Ng'ang'a* and C.R. Vogl
}

Received 17 July 2015, Revised 28 November 2015, Accepted 22 December 2015, Published online 31 December 2015

\begin{abstract}
Austria is one of the major organic tomato producing countries for local and export marketing. These tomatoes are produced in parts of Austria especially around Vienna where their production system has to meet stringent organic quality standards in both local and international markets. These quality standards may put considerable strain on farmers and are normally formulated without famers' participation so may not be wholly representative of the farmers' quality interpretation. The aim of this paper is therefore to determine the Austrian organic tomatoes growers' perception and practice of quality and challenges. Qualitative semi-structured interviews were carried out among 28 organic tomatoes farmers in Vienna, Austria. Findings suggest that quality of organic tomatoes is mainly perceived in terms of both informal values (big fruit size, long shelf life, food security and amount of income received from tomato sales) as well as formal norms (non- application of chemicals, human health, damage free, sweet taste, red colour, and juiciness). There were no gendered differences in quality perception among the growers. High costs of production inputs were identified as the main challenge to attaining quality in organic tomatoes. Following these findings, there is need for effective participation of growers in formulation of standards as well as subsidizing of production inputs by the government. The Austrian tomato growers as well as local and international retailers should work closely to increase the price received by the Austrian organic tomato growers so that it more adequately covers their production costs.
\end{abstract}

Keywords: Quality, Organic, Tomato, Austria, Perception

University of Natural Resources and Life Sciences, Vienna, Gregor Mendel Strasse 33, 1180 Vienna, Austria

*Corresponding author's email: kinotix@yahoo.com (P.K. Ng'ang'a)

\section{Introduction}

Austria is one of the leading producers of organically grown tomatoes in Europe. The majority of these tomatoes are grown for local and international markets where quality is a major prerequisite for access food quality is comprised of the physical and process aspects of food as well as the adherence of these to prescribed standards (Brunsø et al., 2002; Grunert, 1995). In Austria, organic food quality is mainly determined by organic standards formulated in the European Union; these may not necessarily be adequately favorable to the Austrian growers' socio-economic conditions. In addition, the requirements for meeting the international organic standards come with increased certification costs over which the growers have no control (Barrett et al., 2002). Since organic standards (Lyons et al., 2013; Peri, 2006) and international market standards (Allaire, 2010) represent how quality in organic products is perceived in the global market, it is prudent to investigate how Austrian growers for whom the standards are intended perceive quality. This can help reveal the extent of the standards congruence with growers' perception of quality and provide a basis of harmonization of quality standards to grower needs but within the organic principles. In addition, growers' agronomic and post-harvest practices greatly influence the final product quality (Ruben et al., 2005) therefore investigating their field activities aimed at achieving quality also becomes essential.

Generally very few studies addressing quality perception among growers have been done. Moreover, these have been carried out at the global market level and have not focused on the organic sector (Dimara et al., 2004; Ilbery and Kneafsey, 2000). To the best of our knowledge, quality perception of organically grown food among growers in Austria is an area that has not been explored which reveals a big research gap, which this study intended to fill. The specific objectives of this study were: (i) To determine the organic tomato grower's perception of quality in organically grown tomatoes, (ii) To determine the growers' practices aimed at achieving organic quality in tomatoes and (iii) To determine the main challenges of growers face in attaining organic quality. 


\section{Materials and Methods}

\section{The study area and population}

The study was carried out in Vienna area within the country of Austria, which is located in north Eastern Austria and is between N $48^{\circ} 12^{\prime}$ $33.1423^{\prime \prime}$ and $\mathrm{E} 16^{\circ} 22^{\prime} 22.0001^{\prime \prime}$. The region covers a total area of $83,858.00$ sq. $\mathrm{km}$. and a population of about 2.6 million within the metropolitan area. The main language spoken by the local community is German. This area is blessed with fertile soils that favor tomato cultivation.

\section{Study design}

This study followed a qualitative approach and was aimed at getting deep insights into grower's perceptions as seen from their own point of view (Bernard, 1998). Furthermore, we used a mixed methods design that involved both semistructured interviews and structured observations to increase the validity of our research findings (Patton, 1999). The interviews and observations were done during the period March 2015 to June 2015. We purposively selected 28 growers with the advice of the market leaders. This was meant to exclude some growers who were still in the process of conversion to organic farming and those that were originally organic but turned conventional. We also purposively selected 14 men and 14 women growers to avoid bias. Growers were asked what they understood by quality in organic tomatoes, what activities they carried out to attain this quality and challenges they face in attaining quality. The interviews lasted for 40 to 60 minutes and were carried out in the local language German before being translated to English by a language expert from the University of Natural Resources and Life Sciences, Vienna. The interviews were then transcribed using F4 program (Dresing and Pehl, 2012). Structured observations entailed observing the growers routines for tomato cultivation. These were carried out on 10 farms in 2 sessions per day, one in the morning $(6.00 \mathrm{am}-12.00 \mathrm{pm})$ as that's the period growers engage in various agronomic operations. The second session occurred from $5.00 \mathrm{pm}$ to $7.00 \mathrm{pm}$, as this is when growers harvested their produce. At times, the observers questioned the growers on what they were doing in terms of organic tomato quality. Field notes from the observations were documented.

\section{Data analyses}

Data was analyzed carefully by reading the transcripts and creating categories (Glaser and Strauss, 1967) and was done with the help of Atlas qualitative data analysis software (ATLAS.ti, 1999).

\section{Results and Discussion}

What are the grower's perceptions of quality in organically grown tomatoes?

A scrutiny of the results from this study confirms the presence of formal norms and informal values in the grower's perception of quality. The results are thus in line with Selznick's institutional theory of organizations. The results also show both differences and similarities between grower's quality perception and official regulatory requirements (Table 1). As can be seen in table 2, those attributes that aren't reflected in any of the official quality requirements are deemed informal whereas those attributes that appear in at least one official regulation are categorized as formal. Health, non-application of chemicals during production, red colour, sweet taste, juiciness and other environmentally friendly production methods are categorized as normative institutional components because they are either representative of the formal values and norms of IFOAM or the export markets. Food security, longer shelf life and income are categorized as constitutive components because they represent grower's individual needs. Big size and traditional farming methods are categorized as cognitive elements because they are reflective of grower's cultural knowledge and beliefs.

Table 1. Comparison of growers' quality perception with official quality requirements for organically grown tomatoes

\begin{tabular}{lccc}
\hline $\begin{array}{l}\text { Growers quality perception } \\
\text { attributes }\end{array}$ & $\begin{array}{c}\text { Organic standards } \\
\text { requirements }\end{array}$ & $\begin{array}{c}\text { Codex Alimentarius standard } \\
\text { for tomatoes requirements }\end{array}$ & $\begin{array}{c}\text { Importer } \\
\text { requirements }\end{array}$ \\
\hline $\begin{array}{l}\text { Non-application of chemicals } \\
\text { Health and safety }\end{array}$ & $\mathrm{P}$ & $\mathrm{Pb}$ & $\mathrm{Pb}^{\mathrm{b}}$ \\
$\begin{array}{l}\text { Environmental } \\
\text { production methods }\end{array}$ & $\mathrm{P}$ & $\mathrm{Pb}$ & $\mathrm{P}$ \\
Damagefree & $\mathrm{P}$ & $\mathrm{A}$ & $\mathrm{A}$ \\
Colour and ripeness & $\mathrm{A}$ & $\mathrm{P}$ & $\mathrm{A}$ \\
Taste & $\mathrm{A}$ & $\mathrm{P}$ & $\mathrm{P}$ \\
Bigsize & $\mathrm{A}$ & $\mathrm{P}$ & $\mathrm{P}$ \\
Juiciness & $\mathrm{A}$ & $\mathrm{P}$ & $\mathrm{A}^{\mathrm{b}}$ \\
Food security provision & $\mathrm{A}$ & $\mathrm{A}$ & $\mathrm{P}$ \\
Long shelf life & $\mathrm{A}$ & $\mathrm{A}$ & $\mathrm{A}$ \\
Income & $\mathrm{A}$ & $\mathrm{A}$ & $\mathrm{A}$ \\
\hline
\end{tabular}

P- Implies that the attribute in question is present in that particular standard / quality requirement.

A- Implies that the attribute in question is absent in that particular standard / quality requirement.

b- Maximum residue limits specified, c- Recommends a minimum weight of $0.8 \mathrm{~kg}$ and a maximum weight of $2.75 \mathrm{~kg}$, d- Recommended water content up to $18 \%$ maximum.

Source: Adapted from Augstburger et al. (2001); IFOAM (2012) 
Table 2. Institutional nature of the grower's quality attributes depicting their perception

\begin{tabular}{lll}
\hline & \multicolumn{1}{c}{ Quality Perception } & \\
\hline Formal Normative Attributes & Informal ConstitutiveAttributes & Informal Cognitive Attributes \\
\hline -Non-application of chemicals & - Food security provision & -Big fruit size \\
-Health (no contaminants) & - Long shelf life & -Traditional farming methods \\
- Environmental friendly & - High Income & -Red colour \\
production methods & & \\
-Damagefree & & \\
-Sweet taste & &
\end{tabular}

Although, non-application of chemicals is a formal requirement for organic standards, Austrian growers generally have been environmentally conscious and so it is not surprising that they mention it and other environmentally friendly production methods as quality attributes of organic tomatoes. Colour and size exist in both the grower's quality perceptions and the official regulations (Table 1), however, interviews revealed that there were differences in the specifications in what growers preferred and what was demanded by the traders. Although juiciness exists as a quality attribute for both growers and official regulations, it should be noted that unlike growers, in the importer requirements, there is a limit on the amount of juiciness regarded as quality, that is; up to a maximum of $18 \%$ and more importantly for dried fruits (Augstburger et al., 2001). This is probably meant to avoid rotting of the tomato before it reaches its final export destination. Growers associated quality with monetary gains and this is in agreement with some studies that have shown that growers define quality in terms of amount of income received (Concepcion and Montiflor, 2003; Otegbayo et al., 2010). Growers also related quality in organic tomatoes to food security and this also conforms to a number of studies done and reported food security increments among organic tomato growers. They also associated organic tomatoes quality to longer shelf life. Since the attributes of food security provision and income are issues that are non-existent in the current official standard requirements, it is essential that they are somehow addressed in the official regulations (Table 2) if farmers' opinions are to be integrated as in the original organic movements. This is even more logical given that food security is one of the core values of organic farming (Michelsen, 2001). Given that organic premiums appear to have stagnated, income issues can be addressed by setting a minimum and fair amount of monetary compensation growers can receive for their efforts that effectively covers their costs while giving them a fair profit just like in fair trade arrangements. Growers mentioned that traditional farming systems are indicative of organic tomato quality. Such grower's connotations are a clear illustration of influences of traditions on their organic quality perception. Such interpretations are misleading because organic farming is not only about non-application of chemicals (Scialabba and Hattam, 2002). Another interesting feature this study has brought out is that growers did not at all define quality in terms of tomato certification according to organic standards. Even in instances where they defined quality in terms of attributes that are part of the official standards (Table 1), they didn't at all relate such attributes to the standards. This is quite paradoxical given that the growers are trained and inspected for compliance to these attributes in relation to the standards. It shows that they are not aware of the relevance of organic standards certification as a quality indicator, viewing it as rather just something that they have to follow (Dimara et al., 2004). This indicates that organic standards are not developed with their active participation, as they do not seem to understand fully the rationale behind them. Overall, it is evident that local socio-cultural and economic factors play a major role in grower's quality perception.

\section{What are the growers practices aimed at achieving quality in organically grown tomatoes?}

Growers mentioned agronomic and post-harvest handling practices as the main activities they carry out to attain quality. They include early planting, weeding, application of organic fertilizers, non-application of synthetic chemicals as well as careful handling and storage after harvest. These are the elements in the production process of the tomatoes, which are also indicative of the official production guidelines (formal norms) the growers have to follow.

\section{What are the challenges growers endure in attaining quality in organically grown tomatoes?}

The main challenges mentioned by the growers were high production input costs especially labor and organic fertilizers. Similar challenges have been found to hinder organic farming even in some other European countries like Norway (Flaten et al., 2010). The increment in costs was due to the need to utilize more organic fertilizers 
and also carry out frequent weeding in order to get fruits of better intrinsic quality as demanded by the local and export markets. Other challenges mentioned were persistent weeds.

\section{Conclusion}

The results from this study show that the organic tomato growers perceive quality in terms of both informal and formal norms. Some of the informal attributes that related to the physical aspects of the tomatoes were different from what the international market demanded. Growers did not mention product certification according to standards as an indicator of organic quality, which suggests that they probably do not fully understand the whole ideology behind the official regulations. Growers also seem to imply that products from organic farming have the same quality as those from traditional agriculture because both systems do not utilize chemicals. This implies that the quality interpretation in organic tomatoes by these growers may have some slight differences with how quality is defined in the global market. Growers carry out proper agronomic and postharvest practices in a bid to attain organic quality but are hindered mainly by high input costs. The results also suggest that the local socio-cultural and socio economic circumstances have a great influence on how growers interpret quality. Given the above findings it is recommended that Austrian organic growers become more actively involved in the formulation of organic standards as in the original organic certification systems in America. This can enable them to fully internalize the whole idea behind the standards. Growers should also be sensitized more on food security issues as some tend to over concentrate on commercial tomato production while tending to ignore food production. There is a need for the national organic body to continue lobbying government for the enactment of an official organic policy. With such a policy, resources can be set aside to subsidize grower's production costs. Growers also need to be trained more intensively on all the four organic principles as this would enable them comprehend the difference between organic farming and traditional agriculture.

\section{References}

Allaire, G. 2010. Applying economic sociology to understand the meaning of "Quality" in food markets. Agri. Econ. 41: 167-180.

ATLAS.ti $1999 . \quad$ Atlas program. http:/ / www.atlasti.com/index.html.

Accessed 5 J an 2013.

Augstburger, F., Berger, J., Censkowsky, U., Heid, P., Milz, J. and Streit, C. 2001. Organic farming in the tropics and sub tropics: Exemplary description of
Pineapples. Grafelfing, Germany. pp. 333342.

Barrett, H.R., Browne, A.W., Harris, P.J.C. and Cadoret, K. 2002. Organic certification and the UK market: organic imports from developing countries. Food Policy 27(4): 301-318, DOI: $10.1016 /$ S03069192(02)00036-2.

Bernard, H.R. 1998. Handbook of methods in cultural anthropology. Wainut Creek AltaMira Press. pp. 134145.

Brunsø, K., Fjord, T.A. and Grunert, K.G. 2002. Consumers' food choice and quality perception. Aarhus: Aarhus School of Business. pp. 66-74.

Concepcion, S.B. and Montiflor, M.O. 2003. Perceptions of southern mindanao farmers on the quality of temperate vegetables. Paper presented at the 47th Conference of the Australian Agricultural and Resource Economics Society Fremantle, Australia. 1214 February 2003.

Dimara, E., Petrou, A. and Skuras, D. 2004. Agriculturalpolicy for quality and producers' evaluations of quality marketing indicators: a Greek case study. Food Policy 29(5): 485506. DOI: $10.1016 /$ j.foodpol.2004.06.001.

Dresing, T. and Pehl, T. 2012. F4audiotranskription.http://www.audiotran skription.de/ english/contact/about-us. Accessed on $10 \mathrm{~J}$ une. 2015.

Flaten, O., Lien, G., Koesling, M. and Løes, A.K. 2010. Norwegian farmers ceasing certified organic production: Characteristics and reasons. J. Environ. Manage. 91(12): 27172726. DOI: 10.1016/j.jenvman.2010.07.026.

Glaser, B.G. and Strauss, A.L. 1967. The discovery of grounded theory: Strategies for qualitative research. New J ersey: Aldine de Gruyter. pp.221- 232.

Grunert, K.G. 1995. Food quality: A means-end perspective. Food Qual. Pref. 6(3): 171-176. DOI: 10.1016/0950-3293(95)00011-W.

IFOAM. 2012. The IFOAM norms for Organic production and processing: Version 2012. (pp. 1-131). Bonn: IFOAM.

Ilbery, B. and Kneafsey, M. 2000. Producer constructions of quality in regional speciality food production: a case study from south west England. J. Rural Stud. 16(2): 217-230. DOI: 10.1016/S07430167(99)00041-8.

Lyons, K., Palaniappan, G. and Lockie, S. 2013. Organic agriculture governance in the Global South: New opportunities for participation in agricultural development and livelihood outcomes. In: N. Halberg, \& A. Muller (Eds.), Organic Agriculture for Sustainable Livelihoods. London: Routledge. pp. 132-153. 
Michelsen, J. 2001. Organic farming in a regulatory perspective. The Danish case. Sociologia Ruralis, 41(1): 62-84.

Otegbayo, B., Samuel, F., Kehinde, A., Sangoyomi T. and Okonkwo, C. 2010. Perception of food quality in Yams among some Nigerian farmers. African J. Food Sci. 4(8): 541-549.

Patton, M.Q. 1999. Enhancing the quality and credibility of qualitative analysis. Health Serv. Res. 34(5): 1189- 1208.

Peri, C. 2006. The universe of food quality. Food Qual. Pref. 17(1): 3-8. DOI: 10.1016/j.foodqual.2005.03.002.

Ruben, R. Saenz, F. and Zúñiga-Arias, G. 2005. Contracts or rules: quality surveillance in
Costa Rican mango exports. In: G.J. Hofstede (Ed.), Hide or confide? The Dilemma of Transparency. the Emerging World of Chains and : Reed Business Information. pp. 51-58.

Scialabba, N. and Hattam, C. 2002. General concepts and issues in organic agriculture. In: Scialabba, N. and Hattam, C. (eds.) Organic Agriculture, Environment and Food Security, Environment and Natural Resources Series no. 4, Food and Agriculture Organization of United Nations, Rome. pp. 231- 239. 